\title{
Lysobacter koreensis sp. nov., isolated from a ginseng field
}

Correspondence

Deok-Chun Yang

dcyang@khu.ac.kr
The genus Lysobacter was established by Christensen \& Cook (1978) for gliding bacteria with high $\mathrm{G}+\mathrm{C}$ contents that do not produce fruiting bodies, with Lysobacter enzymogenes as the type species. At the time of writing, the genus Lysobacter comprises Lysobacter antibioticus, L. brunescens, L. concretionis, L. enzymogenes and L. gummosus. Except for $L$. concretionis (Bae et al., 2005), these species were proposed by Christensen \& Cook (1978) on the basis of phenotypic characteristics; their taxonomic positions were confirmed by phylogenetic and chemotaxonomic features (Bae et al., 2005). The names of two subspecies of $L$. enzymogenes proposed by Christensen \& Cook (1978), L. enzymogenes subsp. cookii and L. enzymogenes subsp. enzymogenes, were inadvertently omitted from the Approved Lists and these names are therefore not validly published.

In a series of studies, micro-organisms have been isolated from a ginseng field in order to investigate the community structure based on a culture-dependent method. In this study, one strain was isolated from the soil of a ginseng field in Daejeon city, South Korea, and characterized by a polyphasic approach. The polyphasic approach, including phylogenetic analysis based on 16S rRNA gene sequences, genomic relatedness, and chemotaxonomic and phenotypic properties, was conducted to determine the precise

Published online ahead of print on 4 November 2005 as DOI 10.1099/ ijs.0.63955-0.

The GenBank/EMBL/DDBJ accession number for the $16 \mathrm{~S}$ rRNA gene sequence of strain Dae16 ${ }^{\top}$ is $A B 166878$. taxonomic position of strain Dae $16^{\mathrm{T}}$. The results obtained in this study indicated that Dae $16^{\mathrm{T}}$ is a member of the genus Lysobacter, but it is clearly distinguishable from all Lysobacter species. Here, it is proposed that Dae $16^{\mathrm{T}}$ should be classified as the type strain of a novel species.

Strain Dae $16^{\mathrm{T}}$ was isolated from soil of a ginseng field near Daechung lake via direct plating onto R2A agar (Difco). Single colonies on these plates were purified by transferring them onto new plates and subjecting them to an additional incubation for 3 days at $30^{\circ} \mathrm{C}$. Purified colonies were tentatively identified using partial $16 \mathrm{~S}$ rRNA gene sequences.

Cell morphology and motility were observed with a Nikon light microscope $(1000 \times$ magnification $)$, with the cells being allowed to grow for 3 days at $30^{\circ} \mathrm{C}$ on R2A agar. Gram reactions were determined according to the non-staining method, as described by Buck (1982). Oxidase activity was evaluated via the oxidation of $1 \% p$-aminodimethylaniline oxalate. Catalase activity was determined by measurements of bubble production after the application of $3 \%(\mathrm{v} / \mathrm{v})$ hydrogen peroxide solution. Acid production from carbohydrates was assessed using procedures outlined by Cappuccino \& Sherman (2002). Growth at various temperatures $\left(4,15,25,30,37\right.$ and $\left.42{ }^{\circ} \mathrm{C}\right)$ was assessed on $\mathrm{R} 2 \mathrm{~A}$ agar and growth at various $\mathrm{pH}$ values was assessed on R2A broth. Growth on nutrient agar, trypticase soy agar (TSA) and MacConkey agar was also evaluated at $30^{\circ} \mathrm{C}$. The API 20NE and API ID32 GN microtest systems were 
employed in these tests, according to the recommendations of the manufacturer (bioMérieux).

Isoprenoid quinones were extracted with chloroform/ methanol $(2: 1, \mathrm{v} / \mathrm{v})$, purified by TLC and subsequently analysed by HPLC, as described previously (Collins \& Jones, 1981; Shin et al., 1996). In order to perform fatty acid methyl ester analysis, the strains were allowed to grow on TSA for $48 \mathrm{~h}$ at $30^{\circ} \mathrm{C}$ and then two loops of the well-grown cells were harvested. Fatty acid methyl esters were prepared, separated and identified with the Sherlock Microbial Identification System (MIDI; Sasser, 1990).

The genomic DNA of strain Dae $16^{\mathrm{T}}$ was extracted and purified with the QIAGEN Genomic-tip system 100/G; it was then enzymically degraded into nucleosides, as described previously (Tamaoka \& Komagata, 1984; Mesbah et al., 1989). DNA-DNA hybridization was performed fluorometrically, according to the method developed by Ezaki et al. (1989), using photobiotin-labelled DNA probes and micro-dilution wells. Hybridization was conducted with five replications for each sample. The highest and lowest values obtained for each sample were excluded and the means of the remaining three values are quoted as DNA relatedness values.

Genomic DNA was extracted and purified with the Genomic DNA Isolation kit (Core Bio System). The 16S rRNA gene was amplified from chromosomal DNA of strain Dae $16^{\mathrm{T}}$ using the universal bacterial primer set $9 \mathrm{~F}$ and $1512 \mathrm{R}$ (Weisburg et al., 1991) and the purified PCR products were sequenced by Genotec (Daejeon, Korea) (Kim et al., 2005). The full sequence of the 16S rRNA gene was compiled with SeqMan software and the 16S rRNA gene sequences of the test strain were edited using the program BioEdit (Hall, 1999). The 16S rRNA gene sequences of related taxa were obtained from GenBank/EMBL. Multiple alignments were performed with the program CLUSTAL_X (Thompson et al., 1997). Evolutionary distances were calculated using the Kimura two-parameter model (Kimura, 1983). The phylogenetic tree was constructed via the neighbour-joining method (Saitou \& Nei, 1987) in the program MEGA2 (Kumar et al., 2001). Bootstrap analysis with 1000 replicates was also conducted in order to obtain confidence levels for the

Table 1. Differential phenotypic characteristics between strain Dae $16^{\top}$ and related Lysobacter species $^{\circ}$

Strains: 1, L. koreensis Dae $16^{\mathrm{T}}$; 2, L. antibioticus DSM 2044 ${ }^{\mathrm{T}}$; 3, L. brunescens ATCC $29482^{\mathrm{T}}$; 4, L. concretionis KCTC $12205^{\mathrm{T}}$; 5, L. enzymogenes DSM 2043 $;$; 6, L. gummosus ATCC $29489^{\mathrm{T}}$. Data for related taxa were taken from Bae et al. (2005) except results in parentheses, which were taken from Christensen \& Cook (1978). All strains could liquefy gelatin. +, Positive; -, negative.

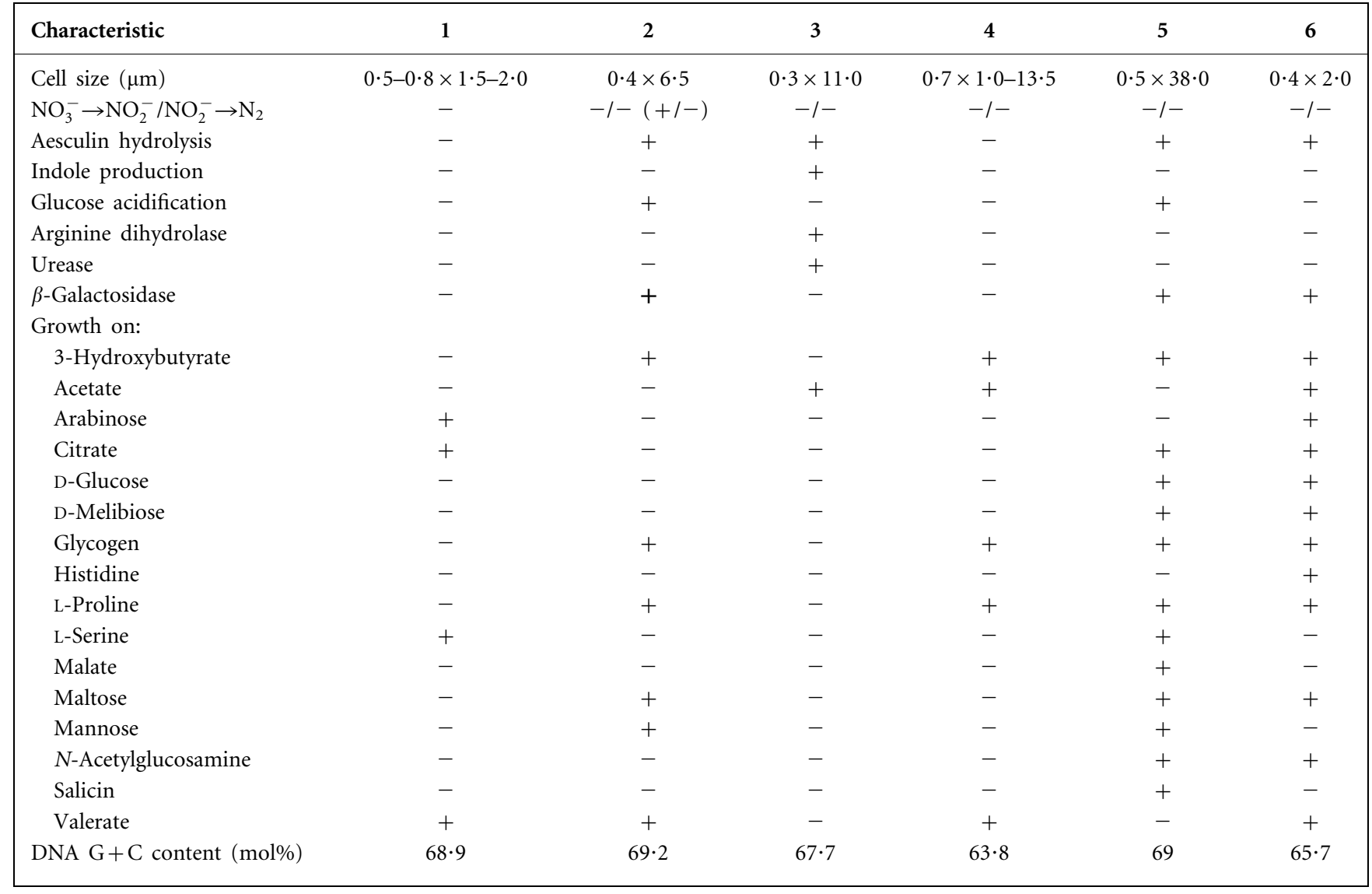


branches (Felsenstein, 1985). All of the species in the genus Lysobacter were included in the phylogenetic tree.

Strain Dae $16^{\mathrm{T}}$ was cultured on R2A agar (Difco) at $30^{\circ} \mathrm{C}$, yielding colonies that were yellow-coloured, circular and glossy in appearance. Strain Dae16 ${ }^{\mathrm{T}}$ was an aerobic, Gramnegative, non-motile, rod-shaped bacterium. Strain Dae $16^{\mathrm{T}}$ was also able to grow at $20-30{ }^{\circ} \mathrm{C}$, but did not grow at 4 or $37^{\circ} \mathrm{C}$. Growth at $30^{\circ} \mathrm{C}$ was not observed on nutrient agar or TSA. The physiological characteristics of strain Dae $16^{\mathrm{T}}$ are summarized in the species description and a comparison of selective characteristics with related type strains is shown in Table 1.

The cellular fatty acid profiles of strain Dae $16^{\mathrm{T}}$ and related Lysobacter type strains are shown in Table 2. The major cellular fatty acids in strain Dae $16^{\mathrm{T}}$ included iso-hexadecanoic acid $\left(\mathrm{C}_{16: 0}\right.$ iso, $\left.33.0 \%\right)$, iso-pentadecanoic acid $\left(\mathrm{C}_{15: 0}\right.$ iso,

Table 2. Cellular fatty acid composition (\%) of strain Dae $16^{\top}$ and related Lysobacter species

Strains: 1, L. koreensis Dae16 ${ }^{\mathrm{T}}$; 2, L. antibioticus DSM 2044 ${ }^{\mathrm{T}}$; 3, L. brunescens ATCC $29482^{\mathrm{T}}$; 4, L. concretionis KCTC $12205^{\mathrm{T}}$; 5, L. enzymogenes DSM 2043 ${ }^{\mathrm{T}}$; 6, L. gummosus ATCC $29489^{\mathrm{T}}$. -, Not detected. Data for related taxa were taken from Bae et al. (2005). For unsaturated fatty acids, the position of the double bond is located by counting from the methyl $(\omega)$ end of the carbon chain; cis and trans isomers are indicated by the suffixes $c$ and $t$, respectively. Summed feature 4 contains $\mathrm{C}_{15: 0}$ iso $2-\mathrm{OH}$ and/or $\mathrm{C}_{16: 1} \omega 7 c$ and summed feature 7 contains $\mathrm{C}_{18: 1} \omega 7 c / \omega 9 t / \omega 12 t$ and/ or $\mathrm{C}_{18: 1} \omega 7 \mathrm{c} / \omega 9 \mathrm{c} / \omega 12 t$, which could not be separated by GLC with the Microbial Identification System (MIDI).

\begin{tabular}{|lcccccc|}
\hline Fatty acid & $\mathbf{1}$ & $\mathbf{2}$ & $\mathbf{3}$ & $\mathbf{4}$ & $\mathbf{5}$ & $\mathbf{6}$ \\
\hline $\mathrm{C}_{10: 0}$ & - & $0 \cdot 9$ & $1 \cdot 3$ & - & - & - \\
$\mathrm{C}_{10: 0}$ iso & $0 \cdot 7$ & - & - & - & - & - \\
$\mathrm{C}_{11: 0}$ iso & $3 \cdot 5$ & $3 \cdot 5$ & $7 \cdot 0$ & $6 \cdot 4$ & $4 \cdot 3$ & $4 \cdot 0$ \\
$\mathrm{C}_{11: 0}$ iso 3-OH & $5 \cdot 6$ & $5 \cdot 2$ & $5 \cdot 6$ & $5 \cdot 6$ & $6 \cdot 0$ & $4 \cdot 4$ \\
$\mathrm{C}_{12: 0}$ iso & $0 \cdot 7$ & - & - & - & - & - \\
$\mathrm{C}_{14: 0}$ & - & $1 \cdot 7$ & $0 \cdot 7$ & $0 \cdot 8$ & $1 \cdot 2$ & - \\
$\mathrm{C}_{14: 0}$ iso & $2 \cdot 7$ & $2 \cdot 3$ & $6 \cdot 7$ & $2 \cdot 6$ & - & - \\
$\mathrm{C}_{15: 0}$ anteiso & - & $5 \cdot 4$ & $1 \cdot 7$ & $1 \cdot 2$ & $1 \cdot 9$ & $5 \cdot 1$ \\
$\mathrm{C}_{15: 0}$ iso & $17 \cdot 0$ & $19 \cdot 9$ & $23 \cdot 8$ & $36 \cdot 1$ & $43 \cdot 0$ & $39 \cdot 3$ \\
$\mathrm{C}_{15: 1}$ iso AT5 & $2 \cdot 7$ & - & - & - & - & - \\
$\mathrm{C}_{16: 0}$ & $2 \cdot 0$ & $10 \cdot 5$ & $1 \cdot 5$ & $2 \cdot 4$ & $5 \cdot 1$ & $7 \cdot 8$ \\
$\mathrm{C}_{16: 0}$ iso & $33 \cdot 0$ & $12 \cdot 1$ & $21 \cdot 9$ & $19 \cdot 9$ & $3 \cdot 0$ & $4 \cdot 7$ \\
$\mathrm{C}_{16: 0}$ iso $\mathrm{H}$ & $1 \cdot 5$ & - & $2 \cdot 7$ & - & - & - \\
$\mathrm{C}_{16: 1} \omega 11 c$ & - & $5 \cdot 5$ & - & - & - & - \\
$\mathrm{C}_{16: 1} \omega 7 c$ alcohol & $4 \cdot 1$ & $3 \cdot 0$ & $0 \cdot 8$ & - & - & $1 \cdot 1$ \\
$\mathrm{C}_{17: 0}$ cyclo & - & $8 \cdot 1$ & - & $2 \cdot 5$ & $10 \cdot 6$ & - \\
$\mathrm{C}_{17: 0}$ iso & $2 \cdot 5$ & $1 \cdot 9$ & $0 \cdot 7$ & $2 \cdot 9$ & $4 \cdot 4$ & $13 \cdot 0$ \\
$\mathrm{C}_{17: 1}$ iso $\omega 9 c$ & $19 \cdot 9$ & $4 \cdot 5$ & $11 \cdot 5$ & $13 \cdot 9$ & $8 \cdot 8$ & $12 \cdot 6$ \\
$\mathrm{C}_{18: 0}$ & $1 \cdot 0$ & - & - & - & - & - \\
$\mathrm{C}_{18: 0}$ iso & $0 \cdot 9$ & - & - & - & - & - \\
Summed feature 4 & $2 \cdot 1$ & $11 \cdot 2$ & $9 \cdot 0$ & $0 \cdot 9$ & $8 \cdot 3$ & $4 \cdot 9$ \\
Summed feature 7 & - & $1 \cdot 3$ & - & - & $1 \cdot 6$ & - \\
\hline & & & & & & \\
\hline
\end{tabular}

$17 \cdot 0 \%)$ and iso-heptadecenoic acid $\left(\mathrm{C}_{17: 1}\right.$ iso $\left.\omega 9 c, 19 \cdot 9 \%\right)$. Minor amounts of the iso-branched fatty acids $\mathrm{C}_{11: 0}$ iso $(3 \cdot 5 \%), \mathrm{C}_{14: 0}$ iso $(2 \cdot 7 \%), \mathrm{C}_{15: 0}$ iso AT5 (2.7\%) and $\mathrm{C}_{17: 0}$ iso $(2 \cdot 5 \%)$ were present and minor amounts of the hydroxy fatty acids $\mathrm{C}_{11: 0}$ iso $3-\mathrm{OH}(5 \cdot 6 \%)$ and $\mathrm{C}_{16: 1} \omega 7 c$ alcohol $(4 \cdot 1 \%)$ were also found. The presence of $\mathrm{C}_{15: 0}$ iso, $\mathrm{C}_{16: 0}$ iso and $C_{17: 1}$ iso $\omega 9 c$ as the major fatty acids is a characteristic composition of genera in the Xanthomonas branch containing the genera Xanthomonas, Pseudoxanthomonas, Stenotrophomonas, Xylella and Luteimonas (Assih et al., 2002; Roumagnac et al., 2004; Yang et al., 2005). Significant differences in fatty acid profiles were found between different species in the genus Lysobacter.

Q-8 was the predominant ubiquinone of strain Dae $16^{\mathrm{T}}$. The quinone system supported our assignment of strain Dae $16^{\mathrm{T}}$ to the Xanthomonas branch, in which the majority of species (including Lysobacter species) also have Q-8 as the predominant quinone.

The 16S rRNA gene sequence of strain Dae $16^{\mathrm{T}}$ was a continuous stretch of $1474 \mathrm{nt}$. The $16 \mathrm{~S}$ rRNA gene sequences of related taxa were obtained from GenBank/EMBL. Strain Dae $16^{\mathrm{T}}$ belonged to the Gammaproteobacteria and had the highest degree of sequence similarity to L. gummosus ATCC $29489^{\mathrm{T}}(97 \cdot 1 \%)$, L. antibioticus DSM $2044^{\mathrm{T}}(96 \cdot 6 \%)$, L. enzymogenes DSM $2043^{\mathrm{T}}(96 \cdot 2 \%)$, L. concretionis KCTC $12205^{\mathrm{T}}(94 \cdot 7 \%)$ and L. brunescens ATCC $29482^{\mathrm{T}}(93 \cdot 7 \%)$. In the phylogenetic tree (Fig. 1), strain Dae16 ${ }^{\mathrm{T}}$ clearly belonged to the Lysobacter lineage, as shown by the high bootstrap value.

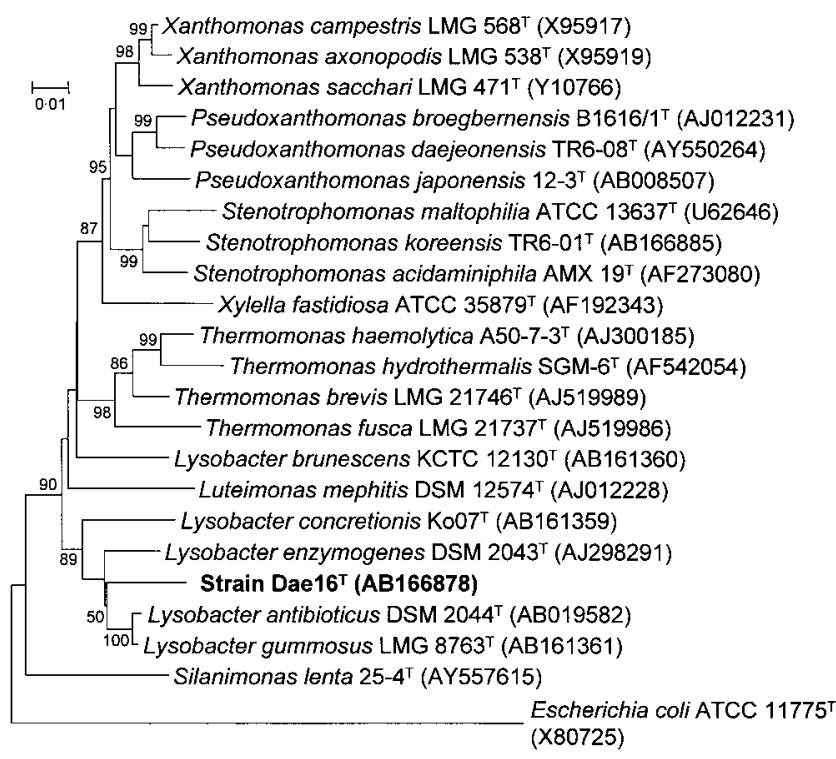

Fig. 1. Phylogenetic tree based on $16 \mathrm{~S}$ rRNA gene sequences showing the phylogenetic relationships between strain Dae16 ${ }^{\top}$ and related species (all Lysobacter species and related genera in the Xanthomonas branch). The neighbour-joining method was used. Bar, 0.01 substitutions per nucleotide position. 
The $\mathrm{G}+\mathrm{C}$ content of the genomic DNA of strain Dae $16^{\mathrm{T}}$ was $68 \cdot 9 \pm 0 \cdot 3 \mathrm{~mol} \%$. Strain Dae $16^{\mathrm{T}}$ exhibited relatively low levels of DNA-DNA relatedness to the type strains L. gummosus ATCC $29489^{\mathrm{T}}(55 \cdot 5 \%)$, L. antibioticus DSM $2044^{\mathrm{T}}(45 \cdot 9 \%)$, L. enzymogenes DSM $2043^{\mathrm{T}}(49 \cdot 0 \%)$ and $L$. concretionis KCTC $12205^{\mathrm{T}}(16 \cdot 6 \%)$. The DNA-DNA hybridization level was less than $70 \%$ (Stackebrandt \& Goebel, 1994), which is the threshold value that delineates a genomic species. Our results support the designation of strain Dae $16^{\mathrm{T}}$ as a representative of a separate, novel species within the genus Lysobacter, for which the name Lysobacter koreensis sp. nov. is proposed.

\section{Description of Lysobacter koreensis sp. nov.}

Lysobacter koreensis sp. nov. (ko.re.en'sis. N.L. masc. adj. koreensis pertaining to Korea, the location of the soil sample from which the type strain was isolated).

Gram-negative, aerobic rods $(1 \cdot 5-2 \cdot 0 \times 0 \cdot 5-0 \cdot 8 \mu \mathrm{m})$ after growth on R2A agar (Difco) at $25^{\circ} \mathrm{C}$ for 10 days. Does not move by flagella. Colonies grown on R2A agar for 2 days are yellow-coloured, glossy circles. Optimal temperature and $\mathrm{pH}$ for growth are $30{ }^{\circ} \mathrm{C}$ and $\mathrm{pH} 6 \cdot 8-8 \cdot 0$. Growth can occur in a salt concentration of $1 \%$, but not above $2 \%$. Catalase-positive and oxidase-negative. Produces protease, but does not produce arginine dihydrolase, urease, $\beta$-glucosidase or $\beta$-galactosidase. Assimilates 3-hydroxybenzoate, citrate, D-mannitol, D-sorbitol, L-arabinose, L-rhamnose, L-serine, propionate and valerate. Does not assimilate 2-ketogluconate, 3-hydroxybutyrate, 4-hydroxybenzoate, 5-ketogluconate, acetate, adipate, caprate, D-glucose, D-maltose, D-mannose, D-melibiose, D-ribose, sucrose, gluconate, glycogen, itaconate, L-alanine, L-fucose, L-histidine, L-proline, lactate, malate, malonate, myo-inositol, $N$-acetylglucosamine, phenylacetate, salicin or suberate. Does not produce any biopolymer-hydrolysing enzymes, e.g. amylase, cellulase, chitinase, DNase, lipase, protease or xylanase. DNA G + C content of the type strain is $68.9 \mathrm{~mol} \%$, as determined by HPLC. Q-8 is the predominant quinone. The major cellular fatty acids are $\mathrm{C}_{16: 0}$ iso $(33 \cdot 0 \%), \mathrm{C}_{15: 0}$ iso, $(17 \cdot 0 \%)$ and $\mathrm{C}_{17: 1}$ iso $\omega 9 c(19 \cdot 9 \%)$. Minor fatty acids are $\mathrm{C}_{11: 0}$ iso $(3 \cdot 5 \%)$ and $\mathrm{C}_{11: 0}$ iso $3-\mathrm{OH}$. Does not reduce nitrate. Can liquefy gelatin. Other phenotypic characteristics, such as substrate utilization and enzyme production, are summarized in Table 1.

The type strain is Dae16 ${ }^{\mathrm{T}}$ (= KCTC $12204^{\mathrm{T}}=\mathrm{NBRC}$ $101156^{\mathrm{T}}$ ), isolated from soil of a ginseng field in Daejeon, South Korea.

\section{Acknowledgements}

This study was carried out with the support of 'Specific Joint Agricultural Research-promoting Projects', RDA, Republic of Korea.

\section{References}

Assih, E. A., Ouattara, A. S., Thierry, S., Cayol, J.-L., Labat, M. \& Macarie, H. (2002). Stenotrophomonas acidaminiphila sp. nov., a strictly aerobic bacterium isolated from an upflow anaerobic sludge blanket (UASB) reactor. Int J Syst Evol Microbiol 52, 559-568.

Bae, H.-S., Im, W.-T. \& Lee, S.-T. (2005). Lysobacter concretionis sp. nov., isolated from anaerobic granules in an upflow anaerobic sludge blanket reactor. Int J Syst Evol Microbiol 55, 1155-1161.

Buck, J. D. (1982). Nonstaining (KOH) method for determination of Gram reactions of marine bacteria. Appl Environ Microbiol 44, 992-993.

Cappuccino, J. G. \& Sherman, N. (2002). Microbiology: a Laboratory Manual, 6th edn. San Francisco: Benjamin Cummings.

Christensen, P. \& Cook, F. D. (1978). Lysobacter, a new genus of nonfruiting, gliding bacteria with a high base ratio. Int J Syst Bacteriol 28, 367-393.

Collins, M. D. \& Jones, D. (1981). Distribution of isoprenoid quinone structural types in bacteria and their taxonomic implication. Microbiol Rev 45, 316-354.

Ezaki, T., Hashimoto, Y. \& Yabuuchi, E. (1989). Fluorometric deoxyribonucleic acid-deoxyribonucleic acid hybridization in microdilution wells as an alternative to membrane filter hybridization in which radioisotopes are used to determine genetic relatedness among bacterial strains. Int J Syst Bacteriol 39, 224-229.

Felsenstein, J. (1985). Confidence limits on phylogenies: an approach using the bootstrap. Evolution 39, 783-791.

Hall, T. A. (1999). BIOEDIT: a user-friendly biological sequence alignment editor and analysis program for Windows 95/98/NT. Nucleic Acids Symp Ser 41, 95-98.

Kim, M. K., Im, W.-T., Ohta, H., Lee, M. \& Lee, S.-T. (2005). Sphingopyxis granuli sp. nov., a $\beta$-glucosidase-producing bacterium in the family Sphingomonadaceae in $\alpha-4$ subclass of the Proteobacteria. J Microbiol 43, 152-157.

Kimura, M. (1983). The Neutral Theory of Molecular Evolution. Cambridge: Cambridge University Press.

Kumar, S., Tamura, K., Jakobsen, I.-B. \& Nei, M. (2001). MEGA2: molecular evolutionary genetics analysis software. Bioinformatics 17, 1244-1245.

Mesbah, M., Premachandran, U. \& Whitman, W. B. (1989). Precise measurement of the $\mathrm{G}+\mathrm{C}$ content of deoxyribonucleic acid by highperformance liquid chromatography. Int J Syst Bacteriol 39, 159-167.

Roumagnac, P., Gagnevin, L., Gardan, L., Sutra, L., Manceau, C., Dickstein, E. R., Jones, J. B., Rott, P. \& Pruvost, O. (2004). Polyphasic characterization of xanthomonads isolated from onion, garlic and Welsh onion (Allium spp.) and their relatedness to different Xanthomonas species. Int J Syst Evol Microbiol 54, 15-24.

Saitou, N. \& Nei, M. (1987). The neighbor-joining method: a new method for reconstructing phylogenetic trees. Mol Biol Evol 4, 406-425.

Sasser, M. (1990). Identification of bacteria by gas chromatography of cellular fatty acids. Technical Note 101. Newark, DE: MIDI.

Shin, Y. K., Lee, J.-S., Chun, C. O., Kim, H.-J. \& Park, Y.-H. (1996). Isoprenoid quinone profiles of the Leclercia adecarboxylata KCTC $1036^{\mathrm{T}}$. J Microbiol Biotechnol 6, 68-69.

Stackebrandt, E. \& Goebel, B. M. (1994). Taxonomic note: a place for DNA-DNA reassociation and $16 \mathrm{~S}$ rRNA sequence analysis in the present species definition in bacteriology. Int J Syst Bacteriol 44, 846-849.

Tamaoka, J. \& Komagata, K. (1984). Determination of DNA base composition by reversed-phase high-performance liquid chromatography. FEMS Microbiol Lett 25, 125-128.

Thompson, J. D., Gibson, T. J., Plewniak, F., Jeanmougin, F. \& Higgins, D. G. (1997). The CLUSTAL_X Windows interface: flexible strategies for multiple sequence alignment aided by quality analysis tools. Nucleic Acids Res 25, 4876-4882. 
Weisburg, W. G., Barns, S. M., Pelletier, D. A. \& Lane, D. J. (1991). $16 S$ ribosomal DNA amplification for phylogenetic study. J Bacteriol 173, 697-703.
Yang, D.-C., Im, W.-T., Kim, M. K. \& Lee, S.-T. (2005). Pseudoxanthomonas koreensis sp. nov. and Pseudoxanthomonas daejeonensis sp. nov. Int J Syst Evol Microbiol 55, 787-791. 